\title{
SPE Asia Conference 2006 参加報告
}

\section{済州島での SPE Asia 2006}

2006 年 6 月 7 日から 9 日までの 3 日間, 韓国の済州島 の済州グランドホテルを会場として The SPE Asian Plastics Technology Conference 2006 が共通テーマ「Bridging the Future with Plastic Technology」の下に開催された.

済州島は韓国の最南端にある火山島で朝鮮半島南端から 約 $100 \mathrm{~km}$ 西南に浮かぶ韓国屈指の観光地として知られて いる. 現在も韓国の新婚旅行のメッカでもある. 周囲約 200 $\mathrm{km}$ 程度と小さい島の中心に標高 $1950 \mathrm{~m}$ の韓国最高峰（漢 拏山）が在り, 島全体が傾斜地で直接海に向かった坂道に なっている．済州市は済州島最大の都会で島の北側にあり， 大きな国際空港を借えていて世界各国からの観光客も多い.

\section{SPE と SPE Asia Conference}

SPE (Society of Plastics Engineers) は, 個人会員によっ て構成されるプラスチックエンジニアの世界的な組織であ る. 本部は米国コネチカット州にあり, 1942 年の創立で プラスチック分野での世界で一番長い歴史を持つ協会であ る. 会員は全世界に 20,000 人以上居り, プラスチックに 関するあらゆる情報の普及活動を行なっている．月刊の機 関紙 Plastics Engineering, Polymer Engineering \& Science を含めて多くの専門的な出版物の発行も実施してい る. 更には国際技術会議 (ANTEC) や地域技術講演会 （RETEC）の開催, 各種セミナーや教育プログラムなど多 岐にわたる活動を特徴としている.

SPE には 60 を超す支部が各地に置かれており，アジア には日本, 韓国, 台湾, 香港, インドの各国とオーストラ リア\&ニュージーランド支部を加えて 6 支部がある. 2001 年秋に開催されたSPEアジア支部長会議で，アジア支部 として組織の重層化を図る案に代わってアジア地区内での 技術交流を行う SPE Asia Conference の設立が議決され た. 第 1 回目はSPE Asia Conference 2003 として, 2003 年 11 月に日本支部が主催して名古屋市で開催した。 今回 はこの Conference の第 2 回目に当る.

\footnotetext{
* Izawa, Shinichi

東京工業大学

東京都目黒区大岡山 2-12-1（†152-8552）

2006.9.10 受理
}

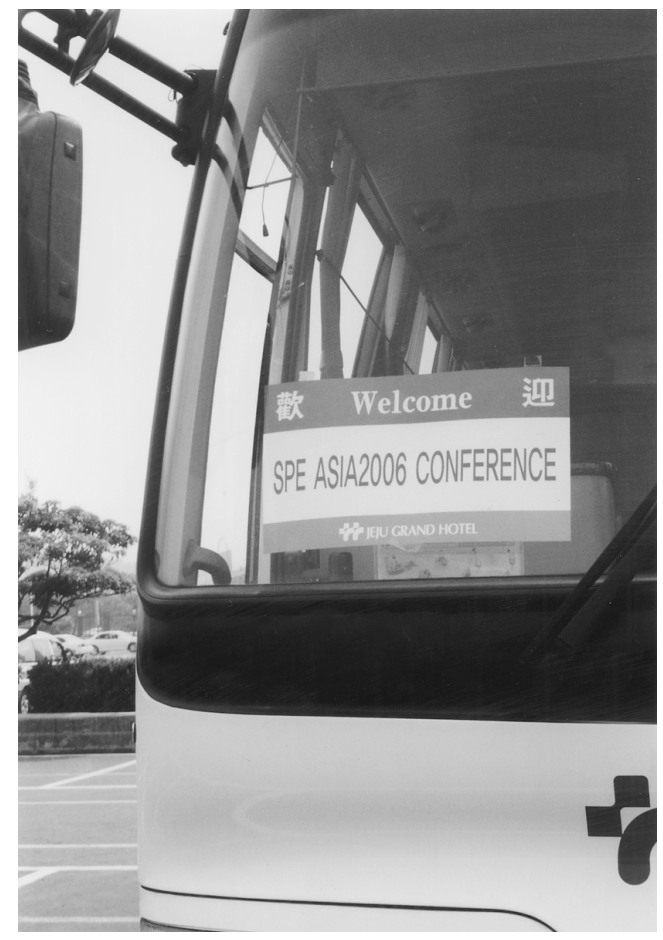

写真 1 国際空港から会場への出迎えバス

\section{SPE Asia Conference 2006 の開会}

開幕日の 6 月 7 日には国際空港に「歓迎 The SPE Asian Plastics Technology Conference 2006」と揭示を出した出 迎えのバスが用意されていて (写真 1 ), 会場にスムース に到着できて丁寧な登録手続きが行なわれた。

初日の定刻午後 5 時に, 今回の国際会議 (SPE Asia Conference 2006）を主催したSPE Koreaの実行委員会から李 暎準氏が登壇して幕が開けられた（写真 2)。その司会の 下で参加者全員が一堂に会して（写真 3，4）開会セレモ ニーが始まった．セレモニー全体がバンケット方式になっ ていて, 開会セレモニー, アジアフォーラム, デイナー, 韓国の民族音楽と踊りを示すパフォーマンスの四つの行事 が行なわれた．開会セレモニーの最初に韓国及び済州島の 紹介がビデオを使って行なわれた，引き続いて，会議全体 の運営に関するスケジュールが発表されると同時にSPE Korea の功績者に対する表彰式が行なわれた.

開会セレモニーに続くアジアフォーラム（SPE Asia Forum）では，アジアから参加した各国のSPE 代表による 


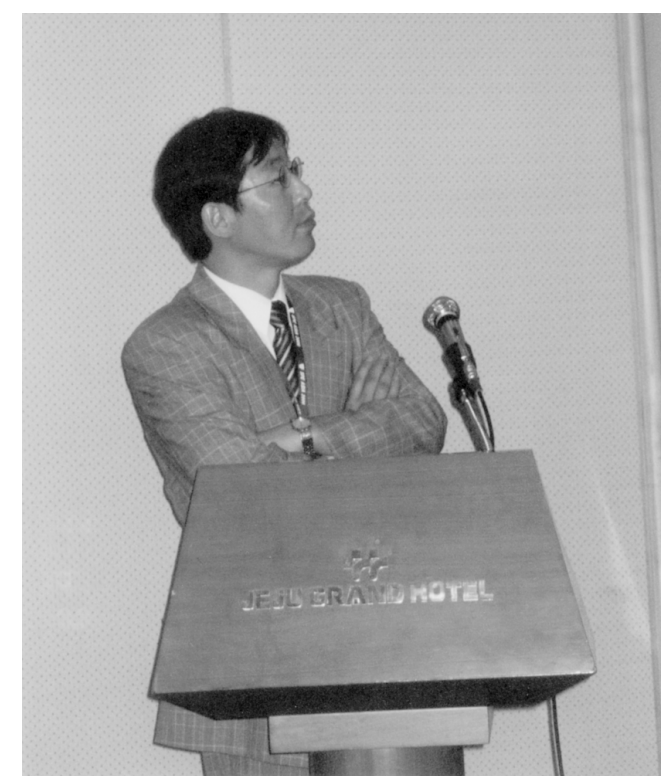

写真 2 開会セレモニーを司会するSPE Korea の李暎準氏

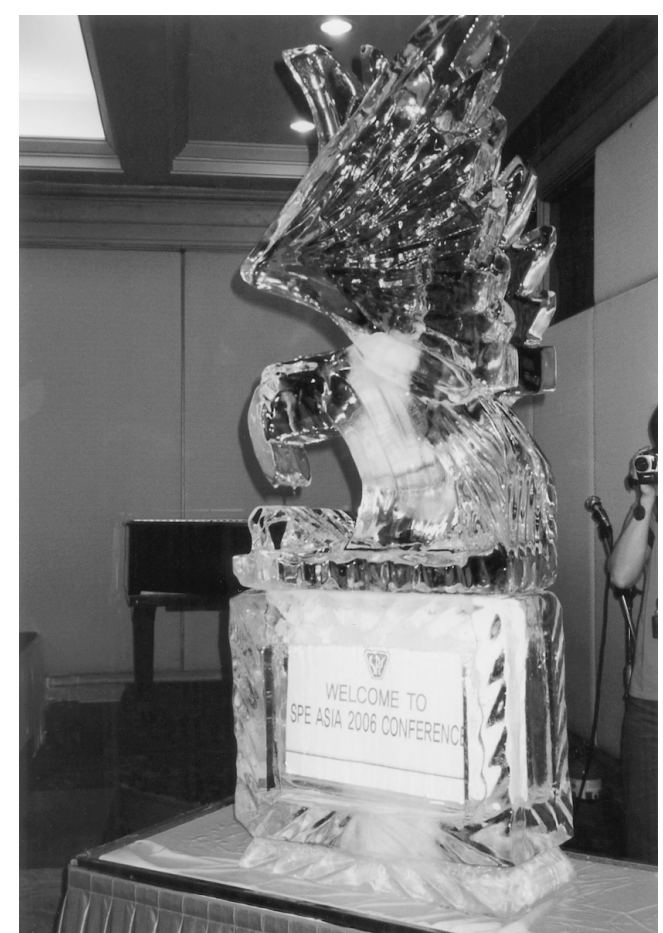

写真 4 会場を飾る氷の彫刻

歴史，現状，展望などの発表が行なわれた。このアジア フォーラムに扫ける各国支部からの活動報告は次の様なも のであったが，6支部の内 3 支部からの出席が無かったの は少々残念であった.

・日本支部からは，今年で満 50 周年を迎える日本での 支部活動の歴史を紹介した，それらに加えて現状の支 部活動をここ 5 年に絞って写真を示しながら説明した. 今年 10 月に実施する 50 周年記念の日本支部 RETEC の企画を紹介して，今回の参加者に訪日を呼びかけた。 ・台湾支部の秘書を務める邱政文氏は，国内固有の SPE

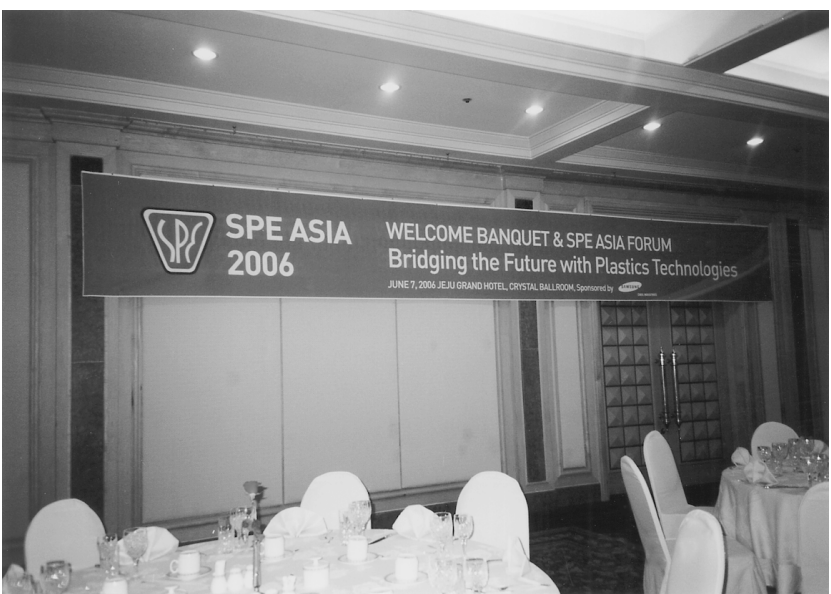

写真 3 開会セレモニー会場の飾り付け

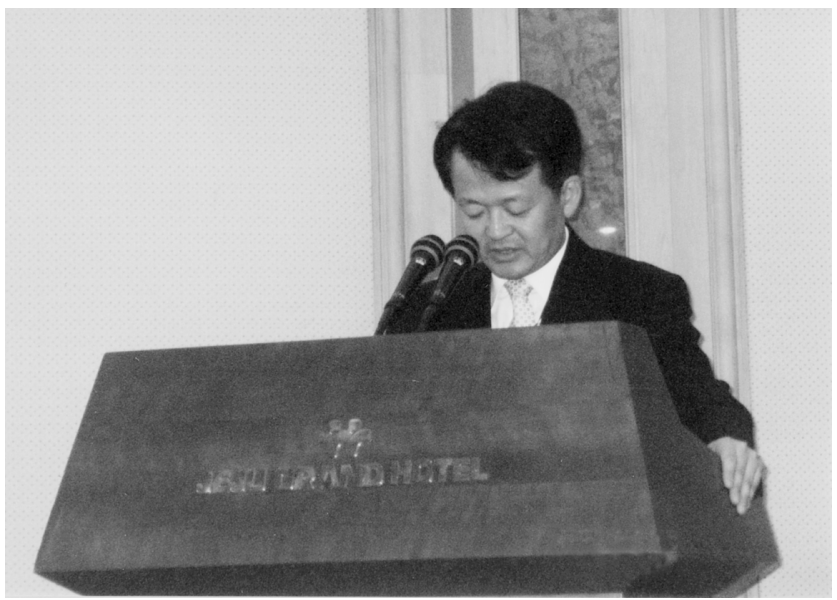

写真 5 SPE Korea の金大植氏の挨拶

会員を集め始めたこの 2 年ほどで，500 名を超える活 動を行なっていることを報告した.

・アメリカ南西部支部からの Dr. Jamal El-Hibri は, SPE 本部のメンバーが参加できなかったのでアメリカから 代表して出席したと述べ，近年メンバーは減少してい るが米国でのSPEの位置は相変わらず高い．活動と してはセミナーの開催，講習会による啓蒙などを中心 とする支部活動を行なっていることを報告した。

・韓国支部は，現支部長の金大植氏（写真 5）が，韓国 のプラスチック工業界の活発な現状を詳しく紹介し，

多数のメンバーがここ済州島に参集していることに感 謝を述べた. 多くの参加メンバーは, 今回の The SPE Asian Plastics Technology Conference 2006 の正式久 ポンサーである 21 社の会社派遣の方々と見受けられ た.SPE 韓国支部は, 毎年支部長が交代しているが, 三 星グループが主体となって支えている。韓国支部の幹 部の殆んどが日本語を理解し, 非常に親近感があった. バンケットはビュッフェスタイルの会食であり（写真 6), このディナーの最中が各参加者による交流の場となってい た．各国からの参加者の皆さんが名刺の交換をしたり旧交 を暖めたりする姿が隋所に見られた．今回の Conference 


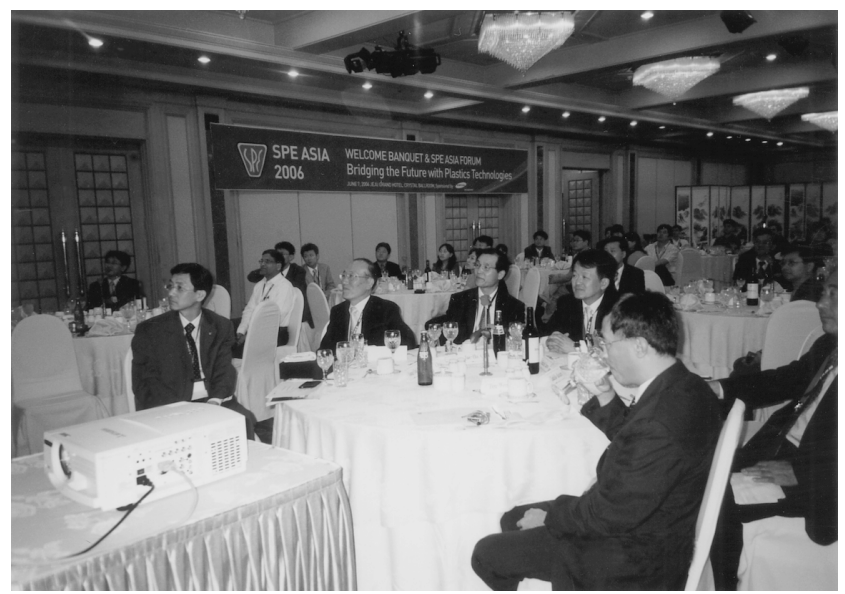

写真 6 バンケット会場風景, 主テーブルには主催者の顔 が見える

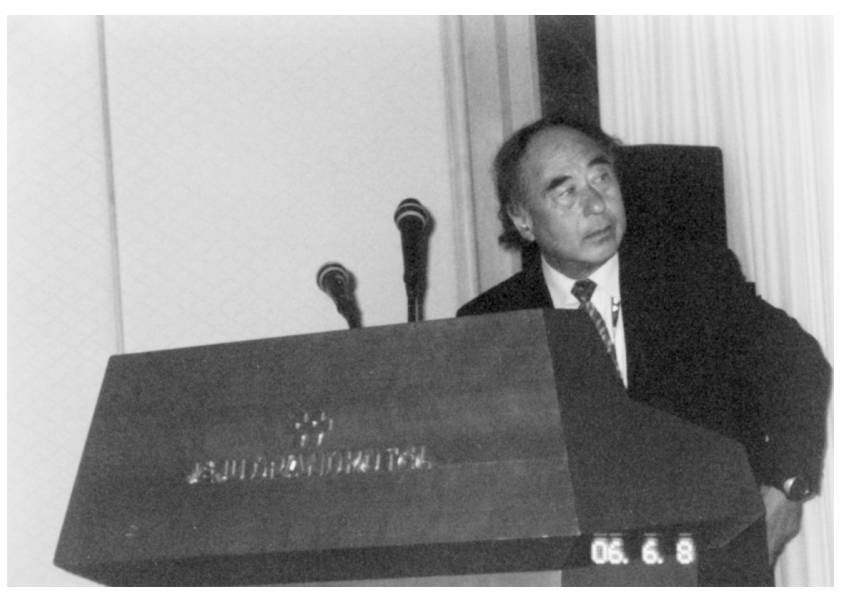

写真 8 Plenary Lecture を行なう葛良忠彦氏

への日本からの参加者は全部で 9 名あり，主だった韓国側 主催者メンバーとの交流を行なった。

会食が進んだ頃合いを見計らって，舞台には韓国の民族 音楽，民族舞踊などの専門家が次々と登場してそれらのパ フォーマンスが示された。写真 7 はその一例である.

\section{技術講演会の内訳}

今回の Conference 2006 に於ける技術報告の発表件数は, 口頭発表が合計で 23 件，ポスター発表は合計で 27 件あっ た.内訳を示すと口頭発表は, SPE Asia Foram が 4 件, Polymer Processing \& Additives が 8 件, High Performance Materials が 5 件, Nanocomposites が 6 件という分 布であった。 ポスター発表は, Polymer Processing \& Additives が 8 件, High Performance Materials が 11 件, Nanocomposites が 8 件という分布であった.

各国からの発表参加数は，口頭発表で，日本からが 7 件, 台湾からが 2 件, 米国からが 2 件あり, それ以外の全ての 口頭発表と全てのポスター発表は, 韓国国内からの参加で あった（その内の 1 名はインドからの留学生で KRITCの 教授との連名であった).

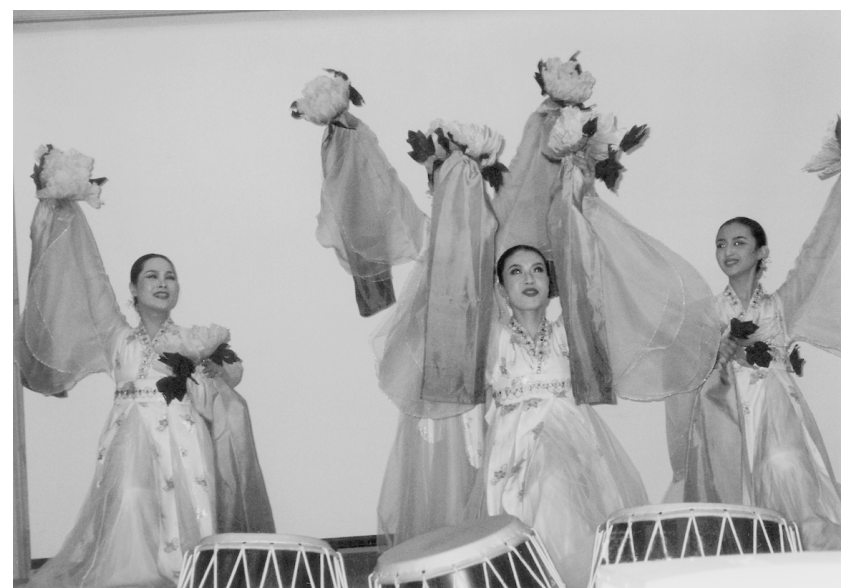

写真 7 韓国の民族舞踊のパフォーマンス

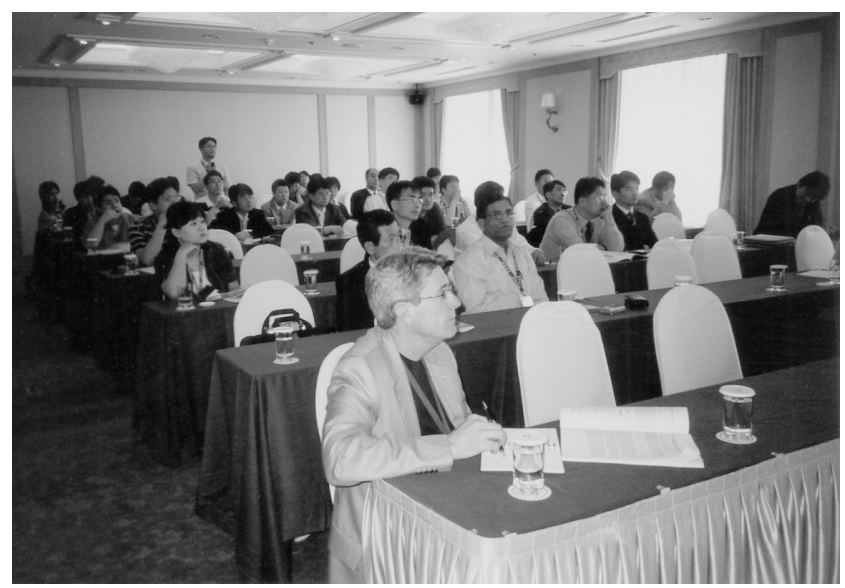

写真 9 討論会の会場風景

日本からプレナリーレクチャーの葛良氏など

第 2 日目の冒頭に全参加者が一堂に会する Plenary Lecture が日本からの葛良忠彦氏によって行なわれた（写真 8). 標題は,「Newest Trends of Blow Molding Technologies」 で，日本でも評判となっている豊富な実例によるブロー成 形技術を紹介された。特に食品包装分野に留まらない広い 工業分野への応用例に注目が集まっていた。

参加発表者の中での日本人発表者の役割は非常に大き かったことが判る. Asia Forumでの日本支部の紹介と葛 良氏の Plenary Lecture の他, 日本からの発表を一通り紹 介する. Polymer Processing \& Additives のセッションで は, 日本製鋼所の菊川健治氏による「Latest Injection Molding Process Technology and its Equipment」，神戸製鋼所 の長岡猛氏による「Long Natural Fiber Reinforced Plastics : Its Properties and Manufacturing Process」の 2 件, High Performance Materials のセッションでは, 日本油 脂の杉浦基之氏による「High Performance Multicomponent Polymer System and Their Applications $\rfloor$ 三菱エン ジニアリングプラスチックの村上幸宣氏による「Polycar- 

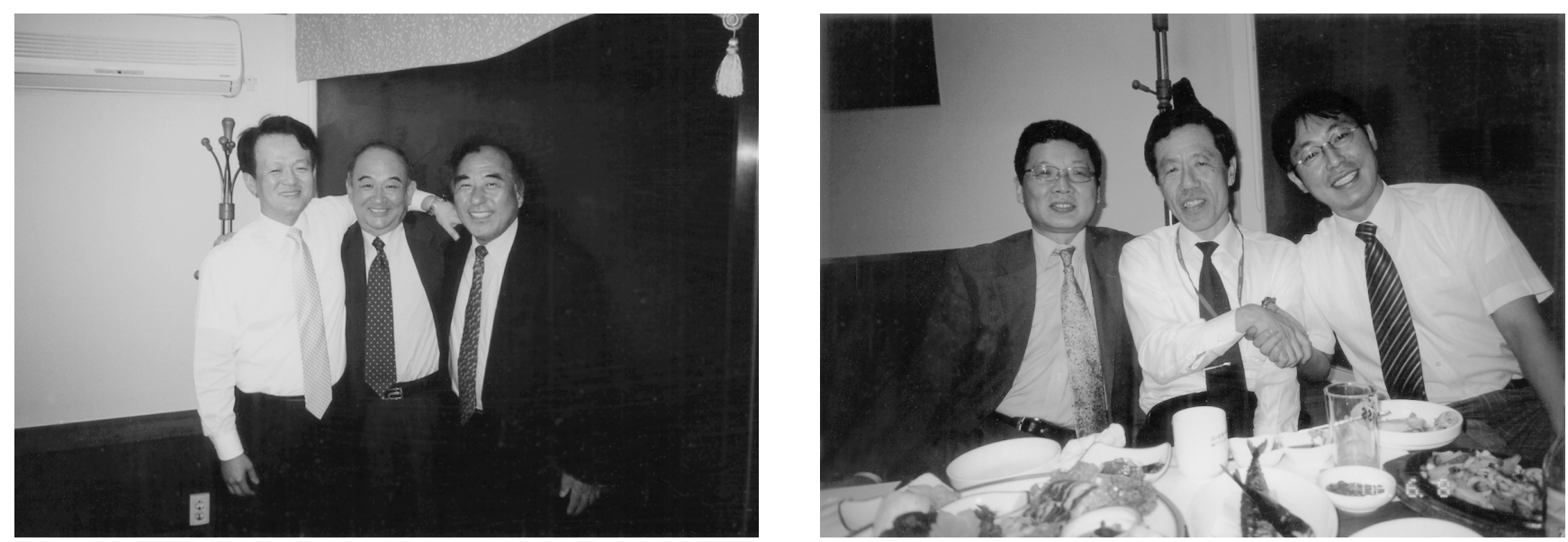

写真 10 海鮮料理のレストランでの国際親睦会のスナップ

bonate Based Material Development for Information Technology」の 2 件, Nanocomposites のセッションでは, 山形大学の高橋辰宏氏による「Alignment Control of MWCNT in Polymer by Magnetic or Electric Field」の 1 件が報告され注目された。討論会は二つの会場に分かれて 実施されたがその一つの会場の風景を写真 9 に示す.

ポスターセッションは 2 日目の午後に会場内の大ホール を利用して行われた. 全てのポスターの表現は英文になっ ていたが，多くの聴衆が韓国人であることもあって，討論 が韓国語になっている部分が多い様に感じられた。

\section{国際交流親睦会}

2 日目の夜には，漁港の一画にある海鮮料理のレストラ ンに場所を移して日本からの参加者を中心とした懇親会を 開催し親交を温めた。日本からの参加者 9 人の内， 6 名が 出席され，韓国の焼酎と共に料理と会話を楽しんだ。同じ レストランで，交流会を行っていた韓国 SPEの主だった 役員の方々とも途中から合流する形となって, 和やかな国 際親睦会となった（写真 10).

次回の SPE Asia Conference 開催を主催する支部とし て，SPE台湾支部にお願いした。

\section{賛助会員ならびに会員の皆様へ}

\section{「知りたい，見たい，訪ねたい一成形加工の元気な仲間一」の 訪問取材を希望される会社を募集中}

「成形加工」誌には，「知りたい，見たい，訪ねたい一成形加工の元気な仲間一」を揭載しています．本企画は， プラスチック成形加工に携わり，日本のものづくり産業の基盤を支えている活気ある企業を，本誌編集委員自ら が訪問取材して，会社概要および自慢の製品・技術を広く会員に紹介することを目的としたもので，詳細は以下 のとおりです。

1. 主として賛助会員あるいは正会員の所属する会社を，本誌編集委員が訪問し，新製品・新技術等を，実際 の製品を見て，あるいは現場見学を交えて取材し，記事としてまとめ上げる．会員による原稿執筆は一切 不要.

2 . 取材は, 2 時間程度.

3. 原稿は, 図表を含めて刷り上がり 2 〜 ページとする.

4. 掲載料は無料.

この「知りたい, 見たい, 訪ねたい一成形加工の元気な仲間一」の訪問取材を是非ご検討下さい.

本企画は，年間 4 5 件を掲載する予定です．記事のスタイル，内容等につきましてはすでに揭載されている 幾つかの記事をご参照下さい.

「成形加工」編集委員長 大嶋正裕 